\title{
Policy Documents of Nepali Technical and Vocational Education and Training: A Critical Discourse Analysis
}

Tikaram Poudel*

School of Education, Kathmandu University, Lalitpur, Nepal

\begin{abstract}
This study critically examines the Technical and Vocational Education and Training (TVET) policy documents of Nepal, not only to understand the specific plans of the government agencies in designing, implementing and expanding TVET programmes but also to problematise discursive practices of TVET programmes in the existing socioeconomic and power hierarchy of Nepali society. More specifically, it aims at understanding the ineffectiveness of these training programmes concerning the target groups. This study makes use of Fairclough's (1995) model of Critical Discourse Analysis of three inter-related dimensions of description, interpretation and explanation within the theoretical framework of capabilities approach (Sen, 2009). The findings indicate that the policy documents of Nepali TVET prioritise the development of semi-skilled human resources for the low-paid international labour market but ignore the conservation and development of indigenous knowledge systems of diverse ethnic communities of Nepal. The study initiates the discourse that integrating indigenous knowledge systems in TVET programmes provides a sustainable model of development.
\end{abstract}

Keywords: TVET, critical discourse analysis, policy review, Nepal

* Editor Email: tikaram.poudel@kusoed.edu.np https://orcid.org/0000-0002-6963-7013 Journal homepages: ${ }^{1}$

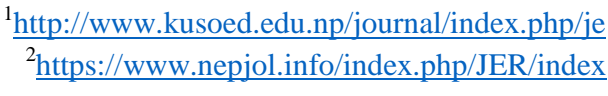

ISSN: 2091-0118 (Print) / 2091-2560 (Online)

(C) 2020 The Editor. Published by Kathmandu University School of Education, Lalitpur, Nepal. 


\section{$2 \mid$ T. Poudel}

\section{Introduction}

To promote the indigenous knowledge systems and skills and to create avenues for employment equipping the youths of Nepal with modern technical education and training, the Government of Nepal established a separate directorate called the Directorate of Technical and Vocational Education (DTVE) as a division of the Ministry of Education in 1982. The Directorate realised the need for coordinating and developing technical education in Nepal. The Government of Nepal passed the Council for Technical Education and Vocational Training (CTEVT) Act in 1988. The CTEVT had twofold objectives: to produce basic, middle level and higher-level technical human resources and to systemise and maintain quality of technical education and vocational training (Government of Nepal, 1998). Prior to the establishment of the CTEVT, all vocational education and training activities were unorganised and scattered. The CTEVT is the autonomous apex body to produce technical and human resource required to move the nation to development by coordinating with national and international organisations for effective planning and implementation (Gupta, 2017).

Initially, when the Act of 1988 was enacted the Council for Technical Education and Vocational Training, the policies were designed to offer technical education for economically disadvantaged youths seeking an immediate source for earning for a living (Government of Nepal, 1988). The CTEVT was established in 1988 to produce a competent, motivated, adaptable, and innovative workforce mainly to address the unemployment of youths and to eliminate poverty and lead the nation to social prosperity and economic development. Since then, the CTEVT has been providing training to youths, particularly from disadvantaged groups, to equip them with a set of skills needed in the immediate market of the nation by way of being a productive and adaptive entrepreneur, or an employee, or self-employed professional. However, the continuous rise in the emigration of unskilled youths in recent decades questions the effectiveness of the training programmes of the CTEVT.

Vocational schools have not been the preferred choice of students from affluent families as these schools prepared students for professions that earned low income in the job market. Families that could not offer regular schools or did not see prospects of studying higher education in universities preferred to send their children to these vocational schools. In the context of Nepal, the school that a child selects for his/her 
study determines the child's life chances because the hierarchical structure of educational institutes is attributed to the quality of education. Our educational system, i.e., guided by the western capitalist ideology, places university education at the top. The most critical factor that determines the choice of an educational institute in Nepal is the financial status of the family, among others, such as the availability of educational institutes in the locality of student's residence. Choice, not a simple concept, is an ideological one that emanated from the concept of free will, an ideology of capitalist economy. In Nepal, the choice of educational institute applies only to a privileged few.

The majority of students enrolled in vocational courses are the inevitable result of constraints, a negative feedback loop to use a term from Puckett et al. (2012), not a choice. The term 'negative feedback loop' refers to the inferiority complex that limits the family to invest in the education of its children because of financial limitations. The political changes in Nepal after the 1990s and the Maoist conflict in the following decades gradually shifted the discourse of educational policies to practice-based and job oriented. This discourse brought the Technical and Vocational Education and Training (TVET) programmes to the forefront at the policy level. The post-conflict policies emphasised the principles of inclusivity; consequently, TVET programmes expanded, despite the negative loop, both in terms of the number of students and programmes offered.

However, there are signs of improvement as technical education has been integrated, at least at the policy level, into the mainstream secondary school education (Ministry of Education, 2016). Many TVET diploma graduates pursue higher education and combine education and work. The Tracer Study Report of CTEVT (2016) reports that 227 graduates of the academic year 2013 opted for higher education. In this context, technical education and training play an important role, not only in improving the skills of most disadvantaged youths over their life course but also the transitions of these students from diploma programmes to higher education and from education to workplace.

TVET programmes and policies are gaining momentum as the relevance of these programmes have been realised, particularly, for lower-income populations. However, there are several problematic issues and needs to be resolved at the policy level. For 


\section{4 | T. Poudel}

example, there is a situation of ambivalence among TVET graduates as they often do not get qualified job opportunities in the job market and as they are not motivated to go for further studies. They do not normally opt for university programmes of higher education since the TVET curriculum often does not prepare them to do so.

This paper is organised as follows: the following section discusses the data and methods adopted for this study. The section after that discusses the TVET policy documents in the socioeconomic contexts of Nepal. After that, TVET policy documents are critically examined from the theoretical frame of capabilities approach (Sen, 2009). The final section concludes the paper with the concluding remarks.

\section{Data and Methods}

This study examines the TVET policy documents of Nepal. The whole corpus of the analysis comprises four TVET policy documents (Table 1), as the major target of analysis, dating from 1988 to 2019. The TVET policy documents analysed in this paper include one act and three policy documents. This study is concerned with the governmental policy documents as the major object of analysis because of their authority and ripple effect upon the TVET programmes in Nepal. With the policy documents, the government officially communicates its policy orientations to various stakeholders such as other governmental departments, related institutions, and educational district offices and schools.

Table 1

List of the Governmental Policy Documents on TVET (1988-2019)

\section{Distribution Title of Documents}

1988 Technical Education and Vocational Training Council Act, 1988

2007 TVET Skill Development Policy, 2007

2012 Technical and Vocational Education and Training Policy, 2012

$2019 \quad$ National Educational Policy, 2019

The methodological perspective of critical discourse analysis, more particularly the model developed by Fairclough $(1989,1995)$ has been applied to understand the 
ideological orientations embedded in the TVET policy documents of Nepal. In this model, the researchers uncover the ideological and power dynamics through texts, discursive practices and social structures (Fairclough, 2003). Critical discourse analysis is both a theoretical framework and a methodology as well. It enables the researchers to assess the meaning of language when it is used to describing and explaining social phenomena (Fairclough, 1995). A critical discourse analyst is interested in studying complex social phenomena that require a multi-disciplinary and multi-methodical approach (Wodak \& Meyer, 2009). The model developed by Fairclough has three dimensions: textual analysis uncovering the formal linguistic properties of the text; the interpretation of the text exploring the discursive practices in which the text was produced; and the explanation of the relationship between discourse and social and cultural reality. In other words, a critical discourse analysis involves, not only in exploring the discursive practices but also in understanding the way texts are produced, consumed and reproduced.

Fairclough's Model $(1989,1995)$ is slightly modified for this paper. The first step in this Model entirely depends on the principles of Halliday's Systemic Functional Linguistics (1985), for example, transitivity analysis. The space of this paper does not permit me to carry out the transitivity analysis of all the TVET acts and policies of Nepal. Therefore, instead of going for the transitivity analysis of these documents, I locate these documents in the discursive practices of the time when these documents were produced. After locating these documents in their respective discursive practices, I interpret and discuss these documents within the theoretical framework of the capabilities approach (Sen, 2009).

\section{Socioeconomic Contexts of TVET Policies}

Following Fairclough's Model (1989, 1995), I take the texts of the TVET act and policies of Nepal and the language used in these texts as a form of social practice (Fairclough \& Wodak, 1997) and a meaning-making process (Rogers et al., 2005, p. 365 ) that form TVET discourse in socially constitutive ways. Applying Fairclough's Model to the analysis of TVET act and policies enables us to understand the way the discourse of TVET is formed in the context of Nepal.

Prior to the TEVT Act of 1988, the activities of technical education in Nepal were scattered and unorganised. One of the objectives of the TEVT Act of 1988 was to 


\section{$6 \mid$ T. Poudel}

systematise and maintain the quality of technical education and vocational training through the process of standardisation (Government of Nepal, 1988). The act envisaged training the human resource of basic, middle and high levels to industrialise the nation. Several internal and external factors were responsible for the enactment of the act. Officially, the modern education system, particularly in the western model, was initiated in Nepal in the 1950s after the recommendations of the Nepal National Education Planning Commission (1956). Although several educational commissions such as All Round National Education Committee (1960) and National Education System Plan (1971) were formed and their recommendations were implemented, Nepal could not industrialise leading to mass unemployment, especially among the youths. Three decades of modern education produced hakims to serve the offices of the panchayat system but failed to transform the national economy. In one sense, this system of education borrowed the ideology of the traditional British Empire system of education that concentrated on producing the human resource to run the empire (Poudel, 2019), the panchayat system in the case of Nepal. In the fiscal year 1982-83, economically, Nepal witnessed a negative growth (The Kathmandu Post, 2015), leading to mass unemployment. This national economic depression compelled policymakers to think of an alternative in the educational system to address this economic crisis.

The shift from the educational system guided by the ideology of colonial legacy to a more job-oriented system of education to address the mass unemployment was influenced by the liberal ideologies of globalisation and regionalism. The regional discursive practices in the educational sector in the context of South Asia, particularly in India, in the decades of the 1980s heavily influenced the ideology of policymakers in Nepal. In 1986, India introduced the National Policy for Educational (NPE) to revamp educational system with the core emphasis on the removal of disparities and to equalise educational opportunity for the marginalised groups such as women, scheduled tribes and scheduled castes communities (Ministry of Human Resource Development, 1986). The NPE had both direct and indirect influences on the policymakers of Nepal, not only because of cultural and geographical proximity with India but also because a large number of high government officials of Nepal received a scholarship to study in Indian universities. The dwindling economic situations in the 1980s compelled the policymakers in Nepal to rejuvenate the economy, engaging available human resources. The immense task before the policymakers was to train the people and equip them for 
the envisioned industrialisation. In such a context, the CTEVT Act of 1988 was enacted to offer technical education for economically disadvantaged youths seeking an immediate source for earning a living (Government of Nepal, 1988).

The year 1990 came with the hope for the people of Nepal. After the movement, a new democratic constitution was promulgated but, before the economic pace could take place, a group of unsatisfied politicians raised one of the bloodiest civil wars of the country in 1996. The rebels halted all kinds of development activities, destroyed the infrastructure, and brought all the economic activities into a standstill. Much to hopelessness, the Royal Massacre of 2001 (Hutt, 2005) and its consequences brought one of the most difficult times for the common people of Nepal. After the Royal Massacre, the political instability and Maoist rebellion dwindled the beleaguered economy. The Comprehensive Peace Accord (PCA) of 2006 formally ended the Maoist rebellion (Government of Nepal, 2006).

After the Maoist conflict in 2006, an Interim Constitution of Nepal 2007 was promulgated. The decade long economic stagnation during the conflict required to be addressed with fast economic growth. For this economic transformation through skill development in a society like ours that faces multiple internal conflicts, the policies required to ensure the positive attitudes of youths from marginalised groups towards skill development for a quality life and attachment to the mainstream society. The recent conflict forced a large number of youths to leave schools, and many more were deprived of the basic right of being literate. These young people have not yet learned the skills to earn their livelihood. The national TVET programmes aim at providing these young people access to technical education and vocational training so that they would be able to live dignified life (Ministry of Education, 2007). In such a context, understanding the changing socioeconomic aspects of Nepali society, the objectives of TVET programmes in Nepal became more inclusive: to ensure the access and inclusion of women, Dalits, ethnic groups, Madhesis and members of other marginalised communities in the mainstream economic activities of the nation through skill development programmes; to ensure the accessibility of training programmes to economically underprivileged human resource living in different parts of the country and linking the outcomes of the skills development with economic demand (Ministry of Education, 2007). 


\section{8 | T. Poudel}

Decade long armed conflict that came to an end in 2006 and political and economic stagnation left thousands of young people without jobs. These people were forced to leave their ancestral homes and moved to urban areas for security reasons. As the educational institutions were completely brought to stagnation during the conflict, these people had to move to abroad as unskilled cheap labourers in the international labour market. Many of them died and many more worked in conditions worse than that of a slave. To address a situation of this kind, the Government brought the Technical and Vocational Education and Training Policy (2012). This document aimed at creating opportunities for employment by preparing capable and competitive human resource for the economic development of the nation through TVET programmes developing a society based on the principles of inclusivity and equity. It also emphasised the preservation and conservation of indigenous knowledge and skills so that indigenous knowledge and skills can be developed for the national and international labour market.

Although the Technical and Vocational Education and Training Policy (2012) was immediately implemented, the results were not as expected. The exodus of unskilled rural folks continued, and more and more young people were forced to work in some of the worst situations in the international labour markets. In terms of socio-political conditions, the second decade of the 21 st century was more peaceful than the previous decade. Maoist rebels came to mainstream politics. They won the 2008 election for the constituent assembly. Despite these improvements in political situations, the nation could not take a pace in economic growth. The April Earthquake of 2015 ravaged the national economy pushing thousands of families to below the poverty line. The immediate economic embargo after the 2015 April Earthquake further escalated the worsening economic situations leading to negative in national economic growth.

After the promulgation of the new constitution in 2015, the Government of Nepal remained busy with the elections at local, provincial and national levels and reconstruction of the infrastructure destroyed by the Earthquake. After 2015 local economic activities gradually increased, leading to gradual economic growth, but these activities were not enough to consume almost half a million young people entering the labour market every year in Nepal. Consequently, a larger number of people continued to go abroad for unskilled labour than ever before. To address the increasing mass unemployment, particularly in rural areas and marginalised communities, the Government had a special provision for Technical and Vocational Education and 
Training in the National Education Policy 2019. The policy intended to prepare able and skilful human resource to create a society based on the principles of inclusivity and equity by expanding the services of technical and vocational education and training (Ministry of Education, 2019).

A critical examination of these documents reveals, not only the implementation plans but also the ideological reflections, prevailing perceptions of the policymakers and their evaluations of realities. These documents define the ideological stance of the policymakers on TVET programmes as a whole. Analysing the policy documents of TVET against the socioeconomic discursive practices reveals that these policy documents envision a development of inclusive society empowering the excluded groups in the mainstream economic activities of the nation. The government agencies, as the dominant subjects become inclusive in their orientations towards ethnic diversity and marginalised groups (Berry, 1991). The policies became more aggressive on the issues of inclusivity and empowering the marginalised after the promulgation of the Constitution of Nepal in 2015 to respect the ethos of the Constitution. Technical and Vocational Education and Training got integrated into mainstream education through the School Sector Development Plan (SSDP) (Ministry of Education, 2016). The SSDP aimed at strengthening the Technical and Vocational Education and Training in secondary school to develop qualified technical human resource capable of earning decent incomes. In this way, the expected outcome of the SSDP was to prepare technically educated and trained human capital for the economic prosperity of the nation (Santwona Memorial Academy, 2017).

\section{TVET for Developing Capabilities for Social Justice}

A closer look at the policy documents of Technical and Vocational Education and Training (TVET) of Nepal reveals that concepts like 'technical human resource', 'capable', 'social justice', 'transformation and prosperity', inclusivity', 'equity', 'access', 'skilful', 'industrious', participatory', 'marginalised communities', 'minorities', 'endangered and backward communities', 'opportunities', etc. reverberate the principles of Sen's (2009) capabilities approach within the wider theoretical framework of social justice. In the context of this paper, I understand Sen's capabilities approach is not limited to teacher's input, outputs of teaching, engagement in teaching and learning process and the resource that creates after the investment in learning but 


\section{$10 \mid$ T. Poudel}

also the condition of being educated and the condition that leads to freedom of mind and supports what the learner has reason to value (Unterhalter, 2007). Enhancing the abilities of an individual is instrumental in minimising social inequality. These inequalities are the product of our deep-rooted social practices, excluding certain groups of people from the principles of social justice. The notion of social justice ensures the equal distribution of resources to reduce poverty and improve the living standards of people (Gautam et al., 2018).

Nepal, ethnically a diverse country, has a very hierarchical society in terms of socioeconomic and cultural practices. These socioeconomic and cultural practices cause barriers for several disadvantaged communities and groups to come to the mainstream social milieu. One of the reasons for being disadvantaged is inaccessibility to resources because they were not able to acquire the required skills. Residence in a rural setting, gender, ethnicity, being Dalit in the caste hierarchy, etc. are some of the major factors that put certain communities or groups into the condition of being disadvantaged in a country like ours. To overcome the condition of being disadvantaged is to equip the members of these communities or groups with the education that transforms them from the condition of disadvantage to the advantage one enabling them to access the resources and ensuring a dignified life. Education in general and TVET, in particular, is instrumental in transforming the disadvantaged to mainstream society by empowering them to exercise their agency through access to information, opportunities and skills.

The general public takes TVET programmes inferior to academic programmes of universities. Looking at the policy documents of TVET from the perspective of the capabilities approach allows us to consider the binary between 'vocational' and 'academic' and 'vocational' being the inferior. These two knowledge systems 'vocational' and 'academic' — are different forms of knowledge and address our contemporary socioeconomic issues differently. However, our TVET policy documents in the last thirty years have not been able to convince the general public that TVET programmes can play a potential role in indigenous knowledge systems concerning human capital and development.

The critical examination of the TVET policy documents reveals that our policymakers always looked outward, never inward. The programmes that CTVET initiated focused on preparing available human resource for low paid semi-skilled 
labour for the international markets of Malaysia or Gulf countries. The policymakers never recognised the potential strength of our indigenous ethnic populations. The capabilities approach takes this as an institutional and cultural barrier, excluding our indigenous knowledge systems of more than a hundred ethnic communities of Nepal. Looking inward for the potential resource is always a prerequisite for sustainable development empowering the indigenous people and giving values to their knowledge systems. Consequently, the TVET programmes could not accelerate the expected economic transformation because these programmes were not designed based on the philosophical foundation of indigenous knowledge systems and cultural relevance to indigenous practices. Since the TVET policies did not prioritise the role of indigenous knowledge systems for the socioeconomic and cultural development of indigenous communities, particularly from rural areas, the indigenous and cultural knowledge eroded as they have been labelled as 'primitive'.

Although the indigenous knowledge system of Nepal received high acclamation in ancient and medieval times, our present educational policies, including TVET ones, contribute to erode this knowledge system that evolved in one of the oldest civilisations of the world. Nepal, a home for more than 120 ethnic communities, preserved diverse indigenous knowledge systems that enabled them to make use of different survival skills that they learned from experience and subsequently passed on from one generation to the next. This process has continued for thousands of years since the age of the hunter-gathering era to the era of agriculture and then to modern times. These communities also went on changing the knowledge and skill as they encountered a new environment as some knowledge systems and skills became irrelevant because of the environmental changes. In contrast, new knowledge systems and skills were developed to adapt to new environments over time.

From preparing the weapons for hunting such as sharpened stones, spears made of wood and later made of metals to the instruments for agriculture such as plough, local hoes, spades, these ethnic communities developed knowledge and skills to capture the artistic imaginations in addition to the needs of survival. Since Nepal, more particularly the Valley of Kathmandu is situated on the trade route of the Indian sub-continent and Tibet including China, the people of this region influenced the civilisations of both India and China and, in return, the knowledge systems of both sides of the Himalayas influenced the people here. The high level of indigenous knowledge and skills that the 


\section{$12 \mid$ T. Poudel}

people of Nepal developed for centuries is well reflected in art, literature, architecture, historical monuments including the carvings on the walls and pillars of temples.

The architectural knowledge and skills that developed in Nepal for centuries are unique and practical. Nepali engineers and artists developed the pagoda architectural construction specifically designed for Hindu temples and stupas for Buddhist religious sites. The architectural feats of Nepali engineers can be observed in the religious sites of the regions of Western Nepal and the magnificent temples in the Valley of Kathmandu such as the Pashupatinath. The most remarkable period of this great tradition reached in the peak in the late medieval period when Araniko, an artist with a great gift of imagination from the Valley of Kathmandu, went to Tibet and China and constructed stupas there (Acharya, 1960). These artists also constructed the palaces for ruling elites and inns merging the local architectural insights and skills with that of outside such as Mughal. Another great example of an engineering feat is the construction of the Royal-canal in the Valley of Kathmandu in ancient times and revived in the 17th century (Aryal, 2005). This canal that was constructed by diverting the water from the River Lele in the southern edge of the Valley fed the stone sprouts (dhunge dhara), drinking water fountains (jahrus), numerous ponds and royal bath with freshwater (Poudel, 2020).

The people of Nepal gave a unique indigenous identity to the artistic constructions from ancient times. Special credit goes to the Newars, an indigenous community of Kathmandu Valley speaking a Tibeto-Burman language, for the creation of religious art (Pal, 1985). The artists from this community have been creating paubha painting, sculpture and metal craftsmanship, renowned for their exquisite beauty since the 14th century (Harris et al., 1964) and this artistic tradition has been passed on from generation to generation as a profession of the family. Stone sculpture, wood carvings found in the temples and historic buildings and statues of Hindu and Buddhist deities found in different parts of Nepal are superb specimens of the traditional artistic heritage of Nepal (Bangdel, 1989). The exposure to the western civilisation in the mid-19th century enabled Nepali artists to merge indigenous artistic genius with the western ones to give a new form of artistic tradition. The credit goes to Chandra Man Maskey and Tej Bahadur Chirtakar who studied art in Calcutta (now Kolkata) under the patronage of the Ranas. The conflict created by the anti-British influence in Bengal and their 
loyalty to pro-British Ranas gave a new direction to the artistic tradition of Nepal (van der Heide, n.d.).

The indigenous knowledge system and skills that evolved among different communities of Nepal since pre-historic times, as outlined above, have never been integrated into the wider educational system of modern Nepal. When the CTEVT Act was drafted in the 1980s, the policymakers of Nepal did not prioritise the importance of indigenous knowledge systems for the economic transformation of the nation. The subsequent TVET policies did not consider essential to conserve and conduct research on indigenous knowledge systems applying them to solve the socioeconomic issues of our times. Consequently, indigenous knowledge systems have never become the dominant discourse of our educational policies, including the policies of TVET.

\section{Conclusion}

The critical analysis of TVET policy documents of Nepal presented in this study revealed that national and regional discursive practices determined the discourse of TVET in Nepal. The national economic depression in the 1980s compelled the policymakers to think of an alternative to general education, leading to the enactment of the CTEVT Act of 1988. The national democratic movement of 1990 and subsequent civic unrest in the 1990s and 2000s dwindled the economic growth resulting in mass unemployment. This situation led to an exodus of labour migrants forced to work in a hazardous situation for low-paid jobs in international labour markets. The TVET policy of 2007 aimed at preparing the migrant workers for the potential jobs but the training and skill development programmes designed by TVET institutions in Nepal did not match the skills required in the labour markets of destination countries. As a result, our migrant workers continued to suffer and did not feel secure in their workplaces. The policies of 2012 and 2019 also did not change the realities of our migrant workers. In the present situation of the COVID-19 Pandemic, millions of unskilled migrant workers in destination countries are forced to return home. In the post-COVID-19 era, a majority of TVET programmes will be irrelevant as they were designed targeting the skills of the international labour market. To integrate the returnee migrant workers, the only way to do is to design the programmes based on indigenous knowledge systems because at least for some years the majority of Nepali migrant workers have the least chances of working abroad. The need of the time is to design programmes that equip 


\section{$14 \mid$ T. Poudel}

the workers not only with the skills required for the workplace but also ensures the freedom of mind and learner's reason to learn what he/she learns as the basic component of the capabilities approach.

\section{References}

Acharya, B. (1960). Araniko: His family and place of birth. Regmi Research Series, $3(11), 241-243$.

Aryal, M. (2005, November). Reviving Patan's royal canal. http://archive.nepalitimes.com/news.php?id=9129\#.X3vAYMIzbIU

Bangdel, L. S. (1989). Stolen images of Nepal. Royal Nepal Academy.

Berry, J. (1991). Understanding and managing multiculturaism. Psychology and Developing Societies, 3(1), 17-49. https://doi.org/10.1177/097133369100300103

Council for Technical Education and Vocational Training. (2016). Tracer study of the graduates of diploma and TSLC programs under CTEVT.

Fairclough, N. (1995). Critical discourse analysis. Longman.

Fairclough, N. (2003). Analysing discourse: Textual analysis for social research. Routledge.

Fairclough, N., \& Wodak, R. (1997). Critical discourse analysis. In T. vanDijk (Ed.), Discourse as social interaction (pp. 258-284). Sage.

Gautam, S., Poudel, T., \& Paudel, P. K. (2018). Technical and vocational education for social transformation and justice. Journal and Education and Research, 8(1), 1-5. https://doi.org/10.3126/jer.v8i1.25474

Government of Nepal. (1988). Technical education and vocational training council act, 1988.

Government of Nepal. (2006). Comprehensive peace accord.

Gupta, B. (2017, June 20). The concept of TVET: Strategy and policy. https://thehimalayantimes.com/opinion/concept-tvet-strategy-policy/

Halliday, M. (1985). An introduction to functional grammar. Edward Arnold.

Harris, G. L., Giddens, J. A., Lux, T. E., Muhlenberg, F., Rintz, F. C., \& Smith, H. H. (1964). Area handbook for Nepal. The American University.

Hutt, M. (2005). King Gyanendra's coup and its implications for Nepal's future. The Brown Journal of World Affairs, 12(1), 111-123.

Ministry of Education. (2012). Technical and vocational education and training, 2012. Government of Nepal.

Journal of Education and Research, Vol. 10, No. 1, 2020 
Ministry of Education. (2019). Nationa educational policy. Government of Nepal. Ministry of Education. (2007). TVET skill development policy, 2007. Government of Nepal.

Ministry of Education. (2016). School sector development plan. Government of Nepal. Ministry of Human Resource Development. (1986). National policy on education. Government of India.

https://mhrd.gov.in/sites/upload_files/mhrd/files/upload_document/npe.pdf

Pal, P. (1985). Art of Nepal: A catalogue of the Los Angeles County Museum of Art Collection. University of California Press.

Poudel, T. (2019). The place of English in educational policy documents of Nepal: A critical discourse analysis. Journal of Nepalese Studies, 12(1).

Poudel, T. (2020). Language, education, and culture. Ujagar, 1 (3), 1-3.

Puckett, J., Davidson, J., \& Lee, E. (2012). Vocational education the missing link in economic development. The Boston Consulting Group.

Rogers, R., Malancharuvil-Berkes, E., Mosley, M., Hui, D., \& Joseph, G. O. (2005). Critical discourse analysis in education: A review of the literature. Review of Educational Research, 75(3), 365-416.

Santwona Memorial Academy. (2017). A study on technical and vocational education in secondary schools as a separate stream: required policies, strategic measures, implementation arrangement and improvements needed in teaching-learning to enhance program effectiveness. Department of Education.

Sen, A. (2009). The idea of justice. Penguin.

The Kathmandu Post. (2015, November 22). Over-reliance on India has hit the economy hard. https://kathmandupost.com/money/2015/11/22/over-reliance-onindia-has-hit-economy-hard: https://kathmadnupost.com

Unterhalter, E. (2007). Gender, schooling and global social justice. Routledge.

Wodak, R., \& Meyer, M. (2009). Critical discourse analysis: History, agenda, theory and methodology. In R. Wodak \& M. Meyer (Eds.), Methods of critical discourse analysis (pp. 1- 33). Sage.

\section{To cite this article:}

Poudel, T. (2020). Policy documents of Nepali technical and vocational education and training: A critical discourse analysis [Editorial]. Journal of Education and Research, 10(1), 1-15. https://doi.org/10.3126/jer.v10i1.31872 